Rev. Int. Contam. Ambie. 35 (1) 259-264, 2019

DOI: 10.20937/RICA.2019.35.01.19

\title{
BIOSORPTION OF CADMIUM AND LEAD USING SUSPENDED AND IMMOBILIZED Enterobacter cloacae AT DIFFERENT PH
}

\author{
Carolina BOJÓRQUEZ ${ }^{1,2}$, Martín Gabriel FRÍAS-ESPERICUETA ${ }^{3 *}$, \\ Bruno GÓMEZ-GIL ${ }^{4}$ and Domenico VOLTOLINA ${ }^{5 \dagger}$
}

${ }^{1}$ Posgrado en Ciencias en Recursos Acuáticos, Facultad de Ciencias del Mar, Universidad Autónoma de Sinaloa, Av. de los Deportes s/n, Ciudad Universitaria, 82000 Mazatlán, Sinaloa, México

${ }^{2}$ Universidad Politécnica de Sinaloa, Unidad Académica de Ingeniería en Tecnología Ambiental, km3 carretera municipal libre Mazatlán-Higueras, Col. Genaro Estrada, 82199 Mazatlán, Sinaloa, México

${ }^{3}$ Facultad de Ciencias del Mar, Universidad Autónoma de Sinaloa, Paseo Claussen s/n, Col. Los Pinos, 82000 Mazatlán, Sinaloa, México

${ }^{4}$ Centro de Investigación en Alimentación y Desarrollo, Unidad Mazatlán, Apdo. Postal 711, 82000 Mazatlán, Sinaloa, México

${ }^{5}$ Centro de Investigaciones Biológicas del Noroeste, Laboratorio UAS-CIBNOR, Facultad de Ciencias del Mar, Universidad Autónoma de Sinaloa, Paseo Claussen s/n, Col. Los Pinos, 82000 Mazatlán, Sinaloa, México

*Corresponding author: friasm@uas.edu.mx

(Received August 2017; accepted April 2018)

Key words: metals, bacterial cultures, absorption, adsorption, biomass production

\begin{abstract}
The aim of this work was to determine the best conditions for biomass production of the bacterium Enterobacter cloacae and for $\mathrm{Cd}$ and $\mathrm{Pb}$ retention by adsorption on the cell walls or by absorption and accumulation in the bacterial biomass. Suspended and immobilized cultures of this bacterium, acclimated to both metals, were grown for $24 \mathrm{~h}$ at $\mathrm{pH} 6,7$ and 9 , in trypticase soy (TS) medium added with $2.73 \mathrm{mg} / \mathrm{L}$ of $\mathrm{Cd}$ or $16.8 \mathrm{mg} / \mathrm{L}$ of $\mathrm{Pb}$. Immobilized cultures at $\mathrm{pH} 7$ and 9 had the highest biomass production. Percentages of $\mathrm{Cd}$ retention by adsorption and absorption increased with increasing $\mathrm{pH}$, but adsorption was higher in suspended while absorption was higher in immobilized cultures. Possibly because of different affinity of bacterial cells for these metals, the percentages of $\mathrm{Pb}$ retention were higher than those of $\mathrm{Cd}$. In percentage, the highest $\mathrm{Pb}$ adsorption on cell walls was at $\mathrm{pH} 9$, while retention by biomass decreased with increasing $\mathrm{pH}$. The amount of metal retained by one $\mathrm{g}$ of bacterial biomass, efficiency was higher at $\mathrm{pH} 6$, possibly because of the presence of dead or dying bacterial cells.
\end{abstract}

Palabras clave: metales, cultivo bacteriano, absorción, adsorción, producción de biomasa

\section{RESUMEN}

En este trabajo se determinaron las mejores condiciones para la producción de biomasa y para la retención de $\mathrm{Cd}$ y $\mathrm{Pb}$ por adsorción en las paredes celulares o por absorción y acumulación en la biomasa bacteriana de Enterobacter cloacae. Con esta finalidad, se mantuvieron durante $24 \mathrm{~h}$ a pH 6,7 y 9 cultivos suspendidos e inmovilizados de esta 
bacteria aclimatada a los dos metales, en medio tripticasa de soya (TS) adicionado con $2.73 \mathrm{mg} / \mathrm{L}$ de $\mathrm{Cd}$ o $16.8 \mathrm{mg} / \mathrm{L}$ de $\mathrm{Pb}$. La mayor producción de biomasa se obtuvo con los cultivos inmovilizados a pH 7 y 9. Los porcentajes de adsorción y absorción de Cd aumentaron con el incremento del pH, pero la adsorción resultó mayor en los cultivos libres, mientras que la absorción fue mayor en los inmovilizados. Los porcentajes de retención de $\mathrm{Pb}$ fueron mayores que los determinados para $\mathrm{Cd}$, posiblemente debido a diferencias en la afinidad de estos metales para las células bacterianas. La mayor adsorción de $\mathrm{Pb}$ en las paredes celulares fue con $\mathrm{pH} 9$, mientras que la retención en la biomasa disminuyó con el incremento del $\mathrm{pH}$. En términos de cantidad de metal retenido por un gramo de biomasa bacteriana, la eficiencia de retención fue mayor a pH 6, posiblemente debido a la presencia de células muertas o poco viables.

\section{INTRODUCTION}

Industrial development produces environmental problems, and among these the most important is the presence of metals in the aquatic environment (Ribeiro et al. 2008). In the case of $\mathrm{Cd}$ and $\mathrm{Pb}$, Mexico is in the fifth position worldwide regarding the production of both metals (Camimex 2017), which explains its presence in aquatic environments of the northwest of the country in relatively high concentrations that could exceed safe levels.

There are several techniques available for the bioremediation of aquatic ecosystems affected by metals. Among these, biosorption consists in the retention of metals dissolved in a liquid medium by substrates of different biological origin, including bacteria resistant or tolerant to metals (Vieira and Volesky 2000).

These microorganisms possess detoxification mechanisms based on the energy-dependent elimination of toxic metals (Silver 1996, Castrillón-Rivera and Palma-Ramos 2012), or they may tolerate the presence of several metals because of their immobilization within or outside their cell wall (Zur et al. 2016).

In previous experiments we showed that an adapted strain of Enterobacter cloacae may grow in cadmium $(\mathrm{Cd})$ or lead $(\mathrm{Pb})$ added TS medium and retain a sizeable fraction of these metals in their biomass (Bojórquez et al. 2016). In this work we evaluated the biosorption capacity of this strain grown at different $\mathrm{pH}$ in suspended and immobilized cultures.

\section{MATERIALS AND METHODS}

The bacterial strain was isolated with standard techniques from a sample of domestic wastewater obtained from the water discharges of the Universidad Politécnica de Sinaloa (Mazatlán, Sinaloa, Mexico).
After its identification with molecular techniques, it was acclimated and maintained in trypticase soy (TS) growth medium with close to 2.8 and $17 \mathrm{mg} / \mathrm{L}$ of $\mathrm{Cd}$ and $\mathrm{Pb}$, respectively (Bojórquez et al. 2016).

Optical density readings obtained in preliminary experiments showed that E. cloacae grew well between $\mathrm{pH} 10$ and 6 , but performed poorly outside this range. Therefore, biomass production in metalfree growth medium and the following retention experiments were performed with suspended and immobilized cultures at $\mathrm{pH}$ values of 6,7 and 9 , in TS medium with the programmed amounts of $\mathrm{Cd}$ or $\mathrm{Pb}$, added as chlorides. The final concentrations, determined by atomic absorption spectrophotometry (Varian SpectrAA-220), were $2.73 \mathrm{mg} / \mathrm{L}$ of $\mathrm{Cd}$ and $16.8 \mathrm{mg} / \mathrm{L}$ of $\mathrm{Pb}$, respectively.

Cultures ( 20 suspended and 20 immobilized) were started with $0.1 \mathrm{~mL}$ of an actively growing culture in $\mathrm{Cd}$ - or $\mathrm{Pb}$-added medium and grown for $24 \mathrm{~h}$ in 20 -mL test tubes with $15 \mathrm{~mL}$ of TS medium added with the respective metal. Immobilized cultures had a $4 \times 6 \mathrm{~cm}\left(48 \mathrm{~cm}^{2}\right.$, considering both sides $)$ of acidtreated grey polypropylene netting of known weight for biofilm support.

The initial $\mathrm{pH}$ of the medium was adjusted to 6,7 and 9 using $\mathrm{HCl}$ or $\mathrm{NaOH}$. After $24 \mathrm{~h}$, cultures were filtered through $4.7 \mathrm{~cm}$ Whatman $\mathrm{GF} / \mathrm{C}$ glass fiber filters of known weight. Suspended and attached bacterial biomass was determined with a semi-micro analytical balance $(0.01 \mathrm{mg})$ after drying separately the filters and the polypropylene support with attached bacteria at $60{ }^{\circ} \mathrm{C}$ for at least $24 \mathrm{~h}$ or until constant weight.

Metal retention was determined in two separate experiments with triplicate cultures. After $24 \mathrm{~h}$ of growth in the respective medium, substrates were removed from the immobilized cultures, gently rinsed with a known volume of metal-free fresh medium, which was added to the original cultures. After this, all cultures were centrifuged at $5000 \mathrm{rpm}(340 \times \mathrm{g})$ 
in a refrigerated centrifuge (Sorvall Legend T, $4{ }^{\circ} \mathrm{C}$ ) for $30 \mathrm{~min}$ and the supernatant was decanted and stored for metal analysis.

The metal adsorbed was separated from the bacterial cell surface vortexing pellets and substrates in $10 \mathrm{~mL}$ of $10 \mathrm{mM}$ ethylenediaminetetraacetic acid (EDTA) (Bashkar and Bhosle 2006). After centrifugation for $15 \mathrm{~min}$, the EDTA was recovered and stored for metal analysis. The resulting pellet was digested in $3 \mathrm{~mL}$ of concentrated nitric acid (Fluka) in a Teflon vessel at $120^{\circ} \mathrm{C}$ for $4 \mathrm{~h}$. Substrates and adhered bacteria were acid-digested with the same technique.

Samples of the acid-digested bacterial biomass diluted with $7 \mathrm{~mL}$ of Milli-Q water, as well as samples of the spent medium and of the EDTA with adsorbed metal, were stored until analysis at $4{ }^{\circ} \mathrm{C}$ in polypropylene vials (Frías-Espericueta et al. 2009). Metal concentrations were determined by atomic absorption spectrophotometry. Data for the spent medium of immobilized cultures were corrected for dilution with the volume of metal-free medium used to rinse the substrate.

For QA/QC blanks were used every 25 samples and the accuracy of the analytical method was evaluated using two certified standard reference materials by the International Atomic Energy Agency, IAEA392 (algae) and IAEA-331 (spinach) (IAEA 2009). Recoveries for $\mathrm{Cd}$ in algae and spinach were 107.02 and $97.31 \%$, respectively. For $\mathrm{Pb}$ in algae, recovery was $90.42 \%$ (Bojórquez et al. 2016).

Mean biomass and mean percentages of metal retained on the surface or within bacterial cells were compared with two-ways ANOVA tests after R1 rank transformation and multiple comparisons HolmSidak tests, with $\alpha=0.05$ (Zar 1996, Conover 2012).

\section{RESULTS}

Biomass production in metal-free growth media was higher for immobilized than for suspended cultures. In both cases, it was similar at $\mathrm{pH} 7$ and 9 (0.600-0.605 and 0.810-0.815 g/L for suspended and immobilized cultures, respectively) and higher than at $\mathrm{pH} 6(0.350$ and $0.450 \mathrm{~g} / \mathrm{L})$ (Table I).

Cadmium retention by extracellular products increased progressively with increasing $\mathrm{pH}$ values and was higher in suspended cultures. Percentages of retention ranged from 3.5 to $8.6 \%$ in suspended and from 1.8 to $6.5 \%$ in immobilized cultures. Absorption in $\mathrm{mg} / \mathrm{g}$ had the same trend, with values ranging from 0.090 to $0.393 \mathrm{mg} / \mathrm{g}$ of bacterial biomass.
TABLE I. MEAN BIOMASS (g/L) ( \pm standard deviation) OF E. cloacae IN SUSPENDED (SC) AND IMMOBILIZED (IC) IN TS MEDIUM WITH INITIAL $\mathrm{pH}$ 6, 7 AND 9

\begin{tabular}{lcc}
\hline $\mathrm{pH}$ & $\mathrm{SC}$ & $\mathrm{IC}$ \\
\hline 6 & $0.350 \pm 0.003 \mathrm{a}$ & $0.450 \pm 0.002 \mathrm{~b}$ \\
7 & $0.605 \pm 0.015 \mathrm{c}$ & $0.815 \pm 0.003 \mathrm{~d}$ \\
9 & $0.600 \pm 0.002 \mathrm{c}$ & $0.810 \pm 0.003 \mathrm{~d}$ \\
\hline
\end{tabular}

Different letters indicate significant differences (two-ways ANOVAs on R1 rank-transformed data, $\alpha=0.05, \mathrm{a}<\mathrm{b}<\mathrm{c}<\mathrm{d}$ )

Cd contained (absorbed) in the microbial biomass was higher than in extracellular products. In all cases values were higher in immobilized cultures, which retained from 17.8 to $52.7 \%$ of the initial value and from 0.598 to $1.779 \mathrm{mg} / \mathrm{g}$ (Table II).

There were no differences in the percentages of $\mathrm{Pb}$ retention by extracellular products, with values ranging from 22.4 to $31.8 \%$ in the suspended cultures at $\mathrm{pH} 6$ and 9, respectively. In terms of mass $(\mathrm{mg} / \mathrm{g})$, retention by immobilized cultures was significantly lower, and the lowest was at $\mathrm{pH} 7$. However, retention by absorption in the microbial biomass was consistently higher in the immobilized cultures, with values decreasing with increasing $\mathrm{pH}$ : retentions at $\mathrm{pH} 6$ were 63.7 and $75.1 \%$, and decreased at $\mathrm{pH} 9$ to 8.2 and $41.9 \%$ in suspended and immobilized cultures, respectively.

Retention in mass units had the same $\mathrm{pH}$-dependent trend, but there were no differences in the amounts of $\mathrm{Pb}$ retained by suspended and immobilized cultures at $\mathrm{pH} 6(30.30$ and $28.06 \mathrm{mg} / \mathrm{g})$ and 7 (9.59 and $10.58 \mathrm{mg} / \mathrm{g}$ ), while at $\mathrm{pH} 9$ retention was lower in suspended cultures $(2.29$ and $8.68 \mathrm{mg} / \mathrm{g}$ ) (Table II).

\section{DISCUSSION}

The higher biomass production in the immobilized cultures observed in the growth experiments coincides with the results obtained by several authors with different bacterial cultures (Garzón-Jiménez and Barragán-Huerta 2008, Martins et al. 2012, 2013, Zur et al. 2016), and is probably explained by the higher availability of dissolved and particulate nutrients adsorbed on the film of extracellular organic compounds used for adhesion by bacterial cells (Cohen 2001, Garrett et al. 2008). This organic film might also participate in metal resistance and retention, through immobilization on its active sites (Lau et al. 2005). 
TABLE II. MEAN RETENTION OF Cd AND Pb IN EXTRACELLULAR PRODUCTS AND BIOMASS OF E. cloacae GROWN IN SUSPENDED (S) AND IMMOBILIZED (I) CULTURES IN TS MEDIUM AT pH 6,7 AND 9, WITH $2.73 \mathrm{mg} / \mathrm{L}$ OF Cd OR $16.8 \mathrm{mg} / \mathrm{L} \mathrm{OF} \mathrm{Pb*}$

\begin{tabular}{lccccc}
\hline $\mathrm{pH}$ & Culture & $\begin{array}{c}\text { Extracellular } \\
(\%)\end{array}$ & $\begin{array}{c}\text { Biomass } \\
(\%)\end{array}$ & $\begin{array}{c}\text { Extracellular } \\
(\mathrm{mg} / \mathrm{g})\end{array}$ & $\begin{array}{c}\text { Biomass } \\
(\mathrm{mg} / \mathrm{g})\end{array}$ \\
\hline 6 & & \multicolumn{5}{c}{$\mathrm{Cd}$} & \\
\hline 7 & $\mathrm{~S}$ & $3.5 \pm 1.3 \mathrm{~b}$ & $6.5 \pm 2.4 \mathrm{~b}$ & $0.28 \pm 0.10 \mathrm{bc}$ & $0.51 \pm 0.11 \mathrm{~b}$ \\
& $\mathrm{I}$ & $1.8 \pm 0.4 \mathrm{a}$ & $23.8 \pm 2.2 \mathrm{~d}$ & $0.11 \pm 0.02 \mathrm{a}$ & $1.45 \pm 0.10 \mathrm{c}$ \\
\hline 9 & $\mathrm{~S}$ & $4.5 \pm 2.2 \mathrm{~b}$ & $2.7 \pm 1.3 \mathrm{a}$ & $0.20 \pm 0.10 \mathrm{~b}$ & $0.12 \pm 0.06 \mathrm{a}$ \\
& $\mathrm{I}$ & $2.7 \pm 1.1 \mathrm{a}$ & $17.8 \pm 2.9 \mathrm{c}$ & $0.09 \pm 0.03 \mathrm{a}$ & $0.60 \pm 0.09 \mathrm{~b}$ \\
\hline & $\mathrm{S}$ & $8.6 \pm 3.3 \mathrm{c}$ & $14.3 \pm 1.5 \mathrm{c}$ & $0.39 \pm 0.10 \mathrm{c}$ & $0.65 \pm 0.06 \mathrm{~b}$ \\
& $\mathrm{I}$ & $6.5 \pm 2.8 \mathrm{c}$ & $52.7 \pm 3.2 \mathrm{e}$ & $0.22 \pm 0.09 \mathrm{~b}$ & $1.78 \pm 0.11 \mathrm{~d}$ \\
\hline 6 & & & & & \\
& $\mathrm{~S}$ & $22.4 \pm 3.5 \mathrm{a}$ & $63.7 \pm 4.3 \mathrm{~d}$ & $10.78 \pm 1.72 \mathrm{e}$ & $30.60 \pm 2.01 \mathrm{~d}$ \\
\hline 7 & $\mathrm{I}$ & $22.8 \pm 4.0 \mathrm{a}$ & $75.1 \pm 6.4 \mathrm{e}$ & $8.52 \pm 1.50 \mathrm{~d}$ & $28.06 \pm 2.42 \mathrm{~d}$ \\
\hline 9 & $\mathrm{~S}$ & $25.5 \pm 2.8 \mathrm{a}$ & $34.5 \pm 3.1 \mathrm{~b}$ & $7.07 \pm 0.80 \mathrm{c}$ & $9.59 \pm 0.80 \mathrm{c}$ \\
& $\mathrm{I}$ & $24.9 \pm 1.6 \mathrm{a}$ & $52.8 \pm 7.0 \mathrm{~d}$ & $5.14 \pm 0.29 \mathrm{a}$ & $10.88 \pm 1.38 \mathrm{c}$ \\
\hline & $\mathrm{S}$ & $31.8 \pm 3.0 \mathrm{~b}$ & $8.2 \pm 1.1 \mathrm{a}$ & $8.89 \pm 0.83 \mathrm{e}$ & $2.29 \pm 0.30 \mathrm{a}$ \\
& $\mathrm{I}$ & $31.0 \pm 3.8 \mathrm{~b}$ & $41.9 \pm 6.1 \mathrm{c}$ & $6.44 \pm 0.71 \mathrm{~b}$ & $8.68 \pm 1.19 \mathrm{~b}$
\end{tabular}

*Values in percentages ( \pm standard deviation) of the initial concentration $(\%)$ and in $\mathrm{mg}$ of $\mathrm{metal} / \mathrm{g}$ of microbial biomass $(\mathrm{mg} / \mathrm{g})$. Different letters indicate significant differences between values in the same column (two-ways ANOVA, and Holm-Sidak tests using R1 rank-transformed data, $\alpha=0.05$, a $<$ b $<\mathrm{c}<\mathrm{d}<\mathrm{e}$ )

Metal retention by bacterial biomass is highly dependent on environmental conditions. Among these, $\mathrm{pH}$ is of paramount importance for the adsorption/absorption process (Kelly et al. 2003, Ahluwalia and Goyal 2007). This is demonstrated by the significant differences in $\mathrm{Cd}$ and $\mathrm{Pb}$ retention at $\mathrm{pH} 9$ in comparison to the remaining $\mathrm{pH}$ conditions.

The only data concerning $\mathrm{Cd}$ and $\mathrm{Pb}$ retention by live cultures of $E$. cloacae refer to experiments performed by Banerjee et al. (2015). In these, Cd retention after one day was equivalent to $22.75 \%$ of the initial concentration, while cultures retained approximately $64 \%$ of the initial $\mathrm{Pb}$. Both values are similar to those obtained at $\mathrm{pH} 7$ in this study, which was the only $\mathrm{pH}$ value used in that experiment.

We could not trace additional examples of studies dealing with metal retention by E. cloacae, but $\mathrm{pH}$-dependent variations of metal retention similar to those of this study were observed in Enterobacter sp. cultures by El-Shanshoury et al. (2013), who found that $\mathrm{Cd}$ retention increased with increasing $\mathrm{pH}$ between 5 and 8 , while in the case of $\mathrm{Pb}$ it decreased significantly in the 8 to $9 \mathrm{pH}$ range.
The importance of $\mathrm{pH}$ for metal biosorption has been stressed by several authors, either because it modifies the uptake process of metals at the membrane level, or due to its effect on metal speciation (surface charges of organic carbon), since both modify the amount of metal available for direct uptake by bacterial cells (Kelly et al. 2003). Besides, acid $\mathrm{pH}$ values used in the present study are similar to those reported by Ruiz-López et al. (2010) in mining waste effluents.

The lower percentages of extra- and endo-cellular $\mathrm{Cd}$, in comparison to those determined for $\mathrm{Pb}$, might be due to the greater affinity for $\mathrm{Pb}$ than for $\mathrm{Cd}$, which was determined experimentally by several authors (Fowle and Fein 1999, Borrock and Fein 2005), or to different mechanisms of detoxification and active expulsion, such as those described by Leedjärv et al. (2008) for both metals and by Hynninen et al. (2009) as an exclusive bacterial detoxification mechanism for $\mathrm{Pb}$.

Generally, high metal retention in immobilized cultures confirms the protective role of the bacterial biofilm. This apparently confers resistance providing binding sites which sequester metals, as was shown for $\mathrm{Pb}$ in several bacterial species which use 
intra- and extra-cellular binding factors to avoid toxicity of water-borne $\mathrm{Pb}$ (Levinson et al. 1996, Roane 1999, Mire et al. 2004).

In spite of the significantly lower biomass at $\mathrm{pH} 6$, removal efficiency measured in units of mass of $\mathrm{Cd}$ removed (including mass determined in extracellular products) by one gram of bacterial biomass, was more

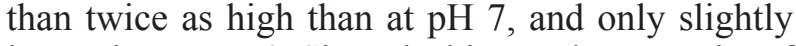
lower than at $\mathrm{pH} 9$. Since the biosorption capacity of viable cells is considerably lower than that of their dead biomass (Kurek et al. 1982, Gabr et al. 2008) these differences are probably due to the poor metal exclusion mechanisms of dead or dying bacterial cells, as observed in suboptimal culture conditions by El-Shanshoury et al. (2013).

\section{CONCLUSIONS}

Biomass production and retention of $\mathrm{Cd}$ and $\mathrm{Pb}$ by E. cloacae are dependent on the $\mathrm{pH}$ of the growth medium: at $\mathrm{pH} 6$, biomass is significant lower than at $\mathrm{pH} 7$ and 9, both in immobilized and suspended cultures. Retention of $\mathrm{Cd}$ by adsorption on microbial cell walls, as well as active absorption within bacterial biomass were higher at $\mathrm{pH} 9$ and significantly better in immobilized cultures.

In the case of $\mathrm{Pb}$, adsorption showed an increasing trend with increasing $\mathrm{pH}$ values, and there were no significant differences between suspended and immobilized cultures. Absorption by biomass was consistently better for immobilized cultures and values were significantly higher at $\mathrm{pH} 6$ (as reported in some mining effluents) than at $\mathrm{pH} 7$ and 9.

\section{ACKNOWLEDGMENTS}

Supported by the Universidad Politécnica de Sinaloa (UPSIN) research funds and through the Consejo Nacional de Ciencia y Tecnología INFRA-2012-01-188029, Programa para el Desarrollo Profesional Docente CANE-year 3 and Programa de Fomento y Apoyo a Proyectos de Investigación UAS $2015 / 103$ grants. The first author is the recipient of a Consejo Nacional de Ciencia y Tecnología scholarship. H. Bojórquez helped with metal analysis.

\section{REFERENCES}

Ahluwalia S.S. and Goyal D. (2007). Microbial and plant derived biomass for removal of heavy metals from wastewater. Bioresource Technol. 98 (12), 2243-2257. DOI: 10.1016/j.biortech.2005.12.006

Banerjee G., Ray A.K., Askarian F. and Ringo E. (2015). Bioremediation of heavy metals by a novel bacterial strain Enterobacter cloacae and its antioxidant enzyme activity, flocculant production, and protein expression in presence of lead, cadmium, and nickel. Water Air Soil Pollut. 226 (4), 91-99.

DOI: $10.1007 / \mathrm{s} 11270-015-2359-9$

Bhaskar P.V. and Bhosle N.B. (2006). Bacterial extracellular polymeric substance (EPS): A carrier of heavy metals in the marine food-chain. Environ. Int. 32 (2), 191-198. DOI: 10.1016/j.envint.2005.08.010

Bojórquez C., Frías-Espericueta M.G. and Voltolina D. (2016). Removal of cadmium and lead by adapted strains of Pseudomonas aeruginosa and Enterobacter cloacae. Rev. Int. Contam. Ambie. 32 (4), 407-412. DOI: 10.20937/RICA.2016.32.04.04

Borrok D.M. and Fein J.B. (2005). The impact of ionic strength on the adsorption of protons, $\mathrm{Pb}, \mathrm{Cd}$, and $\mathrm{Sr}$ onto the surfaces of gram negative bacteria: Testing nonelectrostatic, diffuse, and triple-layer models. J. Colloid Interf. Sci. 286 (1), 110-126.

DOI: $10.1016 /$ j.jcis.2005.01.015

Camimex (2017). Estadísticas. Informe anual 2010. Cámara Minera de México [on line] http://camimex.org. $\mathrm{mx} /$ publicaciones/info2010.pdf 28/11/2017

Castrillón-Rivera L.E. and Palma-Ramos A. (2012). Biofilms: A survival and resistance mechanism of microorganisms. In: Antibiotic resistant bacteria - A continuous challenge in the new millennium (M. Pana, Ed.). Intech, London, UK, 159-178.

Cohen Y. (2001). Biofiltration the treatment of fluids by microorganisms immobilized into the filter bedding material: A review. Bioresource Technol. 77 (3), 257274. DOI: $10.1016 / \mathrm{S} 0960-8524(00) 00074-2$

Conover W.J. (2012). The rank transformation-an easy and intuitive way to connect many nonparametric methods to their parametric counterparts for seamless teaching in introductory statistics courses. WIREs Comput. Stat. 4 (5), 432-438. DOI: 10.1002/wics. 1216

El-Shanshoury A.E., Elsilk S.E. and Ateya P.S. (2013). Uptake of some heavy metals by metal resistant Enterobacter sp. isolate from Egypt. Afr. J. Microbiol. Res. 7 (23), 2875-2884. DOI: 10.5897/AJMR12.1352

Fowle D.A. and Fein J.B. (1999). Competitive adsorption of metal cations onto two grampositive bacteria: Testing the chemical equilibrium model. Geochim. Cosmochim. Acta 63 (19-20), 3059-3067. DOI: 10.1016/S0016-7037(99)00233-1

Frías-Espericueta M.G., Osuna-López J.I., Voltolina D., Beltrán-Velarde M., Izaguirre-Fierro G., López-López G., Muy-Rangel M.D. and Rubio-Carrasco W. (2009). 
The content of $\mathrm{Cd}, \mathrm{Cu}, \mathrm{Pb}$ and zinc of the white shrimp Litopenaeus vannamei of six coastal lagoons of Sinaloa, NW Mexico. Rev. Biol. Mar. Oceanogr. 44 (1), 197-201. DOI: 10.4067/S0718-19572009000100020

Gabr R.M., Hassan S.H.A. and Shoreit A.A.M. (2008). Biosorption of lead and nickel by living and nonliving cells of Pseudomonas aeruginosa ASU 6a. Int. Biodeter. Biodegr. 62 (2), 195-203.

DOI: 10.1016/j.ibiod.2008.01.008

Garrett T.R., Bhakoo M. and Zhang Z. (2008). Bacterial adhesion and biofilms on surfaces. Prog. Nat. Sci. 18 (9), 1049-1056. DOI: 10.1016/j.pnsc.2008.04.001

Garzón-Jiménez C. and Barragán-Huerta B.E. (2008). Inmovilización microbiana: técnicas y usos en el tratamiento de residuos tóxicos. Rev. Sistem. Ambie. 2 (1), 23-34.

Hynninen A., Touzé T., Pitkänen L., Mengin-Lecreulx D. and Virta M. (2009). An efflux transporter PbrA and a phosphatase $\mathrm{PbrB}$ cooperate in a lead-resistance mechanism in bacteria. Mol. Microbiol. 74 (2), 384394. DOI: $10.1111 /$ j.1365-2958.2009.06868.x

IAEA (2009). Reference material online catalog. International Atomic Energy Agency [online]. http://nucleus. iaea.org/rpst/ReferenceProducts/ReferenceMaterials/ $16 / 09 / 2017$

Kelly C.A., Rudd J.W.M. and Holoka M.H. (2003). Effect of $\mathrm{pH}$ on mercury uptake by an aquatic bacterium: implications for $\mathrm{Hg}$ cycling. Environ. Sci. Technol. 37 (13), 2941-2946. DOI: 10.1021/es026366o

Kurek E., Czaban J. and Bollag J.M. (1982). Sorption of cadmium by microorganisms in competition with other soil constituents. Appl. Environ. Microbiol. 43 (5), 1011-1015.

Lau T.C., Wu X.A., Chua H., Qian P.Y. and Wong P.K. (2005). Effect of exopolysaccharides on the adsorption of metal ions by Pseudomonas sp. CU-1. Water Sci. Technol. 52 (7), 63-68. DOI: 10.2166/wst.2005.0182

Leedjärv A., Ivask A. and Virta M. (2008). Interplay of different transporters in the mediation of divalent heavy metal resistance in Pseudomonas putida KT2440. J. Bacteriol. 190 (8), 2680-2689.

DOI: 10.1128/JB.01494-07

Levinson H.S., Mahler I., Blackwelder P. and Hood T. (1996). Lead resistance and sensitivity in Staphylococcus aureus. FEMS Microbiol. Lett. 145 (3), 421-425. DOI: 10.1016/S0378-1097(96)00443-0
Martins S.C.S., Martins C.M., Oliveira A.V., Fiúza L.M.C.G. and Santaella S.T. (2012). Selection of culturable environmental microbial strains for cellular immobilization: Association of phenotypic adhesive characteristics and quantitative cellular retention. Afr. J. Biotechnol. 11 (58), 12206-12212. DOI: 10.5897/AJB12.1397

Martins S.C.S., Martins C.M., Fiúza L.M.C.G. and Santaella S.T. (2013). Immobilization of microbial cells: A promising tool for treatment of toxic pollutants in industrial wastewater. Afr. J. Biotechnol. 12 (28), 44124418. DOI: $10.5897 / A J B 12.2677$

Mire C.E., Tourjee J.A., O’Brien W.F., Ramanujachary K.V. and Hecht G.B. (2004). Lead precipitation by Vibrio harveyi: Evidence for novel quorum-sensing interactions. Appl. Environ. Microbiol. 70 (2), 855864. DOI: 10.1128/AEM.70.2.855-864.2004

Ribeiro N., Lepes A. and Fachini A. (2008). Cleansing contaminated seawaters using marine cyanobacteria: evaluation of trace metal removal from the medium. Int. J. Environ. Anal. Chem. 88 (10), 701-710. DOI: $10.1080 / 03067310802061629$

Roane T.M. (1999). Lead resistance in two bacterial isolates from heavy metal-contaminated soils. Microb. Ecol. 37 (3), 218-24. DOI: 10.1007/s002489900145

Ruiz-López V., González-Sandoval M.R, Barrera-Godínez J.A., Moeller-Chávez G., Ramírez-Campero E. and Durán-Domnínguez de Bazúa M.C. (2010). Remoción de $\mathrm{Cd}$ y $\mathrm{Zn}$ de una corriente acuosa de una empresa minera usando humedales artificiales. Tecnología, Ciencia, Educación 25 (1), 27-34.

Silver S. (1996). Bacterial resistances to toxic metal ions - A review. Gene 179 (1), 9-19.

DOI: $10.1016 / \mathrm{S} 0378-1119(96) 00323-\mathrm{X}$

Vieira R. and Volesky B. (2000). Biosorption: A solution to pollution? Int. Microbiol. 3 (1), 17-24.

Zar J.H. (1996). Biostatistical analysis. Prentice-Hall, Englewood Cliffs, USA, 620 pp.

Zur J., Wojcieszyńska D. and Guzik U. (2016). Metabolic responses of bacterial cells to immobilization. Molecules 21 (7), E958. DOI: 10.3390/molecules21070958 